\title{
Corporate Communication in European Financial Institutions
}

\begin{abstract}
In 1988 the Rotterdam School of Management and Fairfield University conducted jointly a survey in twenty-one banks and twenty insurance companies in Europe and the U.S. The purpose was to examine corporate communication practices in comparable service industries on two continents.

Central questions were: How is corporate communication organized; how are resources allocated; what strategies are used; what values are reflected in different communication activities such as advertising, public relations, communication relations, and employee communication; how are messages shaped for diverse audiences and customer groups; and how much importance is attached to corporate identification symbols.

This article reports on the European results of that survey. The completc report is published in van Riel \& Nedela, Profiles in Corporate Communication in Financial Institutions, Eburon, Delft, 1989. Dr. van Riel is director of the Corporate Communication Centre, Erasmus University, Rotterdam, the Netherlands.
\end{abstract}

Corporate communication can be described as:

Corporate communication is a management instrument with which all consciously practiced forms of both internal and external communication are 


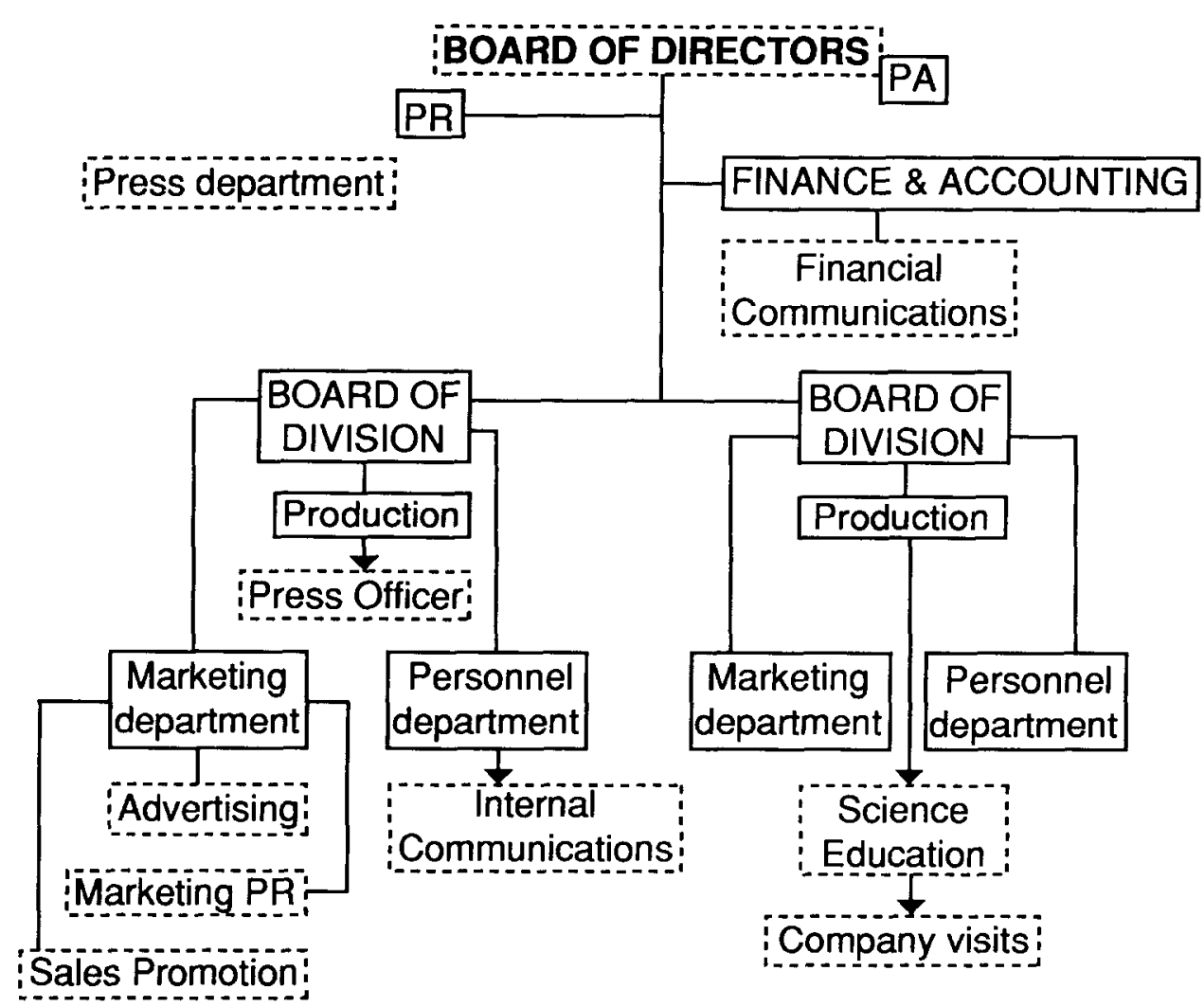

Figure 1. Organizational Chart: Diversity of Communication Specializations

attuned to each other in such a way that the organization acquires and sustains the intended image with its most important target groups.

It is generally accepted that the attunement of all forms of communication is of great importance for an effective use of communication as a management instrument. An often occurring problem in this respect is the fragmentation of the communication-function within a business firm. A hypothetical organizational chart of an industrial business firm illustrates the variety of specializations and locations of communication within a corporation.

PR/PA and Press Contacts at corporate head quarters level, marketing communication, and marketing PR at division level. You do not have to be a communication expert to conclude that this can cause problems: e.g. the annual report tries to impress financial target groups by presenting an image of the organization as a world giant, while advertising for new employees projects a rather local organizational image.

In an ideal situation, a corporation tries to avoid these problems by attuning all communication modalities to each other. This is one of the main characteristics of a corporate communication program. 
Banks and insurance companies spend millions of dollars, francs, marks or guilders on communication. The reasons are obvious: they want to increase the awareness about their company, its products or its services; establish a favorable attitude towards the company; and increase understanding and appreciation of the firm. All are aimed, of course, at creating a sound foundation for a commercial relationship between the company and its publics. In general corporate communication activities are aimed at improving the image of a company.

Corporate image is the reflection of the identity of a bank or an insurance company with its main stakeholders. Corporate identity is the projection of a clear idea about what the company is and what it aims to be. Like "marketing," corporate identity consists of a mix of four ingredients: personality, behavior, symbolism and communications. Symbolism (referring to logo, design, etc.) and communications (media used) are the more traditional aspects of corporate identity. Corporate personality can be defined by answering questions such as: "what does the company stand for," "what markets are they in;" etc. Corporate behavior applies to the achievements of an organization, like the ranking position in their market.

The relation between corporate identity and corporate image is shown in Figure 2.

This model is developed by the German authors Birkigt and Stadler (1986). It shows clearly that corporate image is a reflection of corporate identity. Or as the Germans say: corporate identity is your Selbstbild while corporate image is your Fremdbild.

The just mentioned philosophy of corporate communication is used as a starting point to develop a questionnaire to investigate the way corporate communication is practiced in European and U.S. banks and insurance companies.

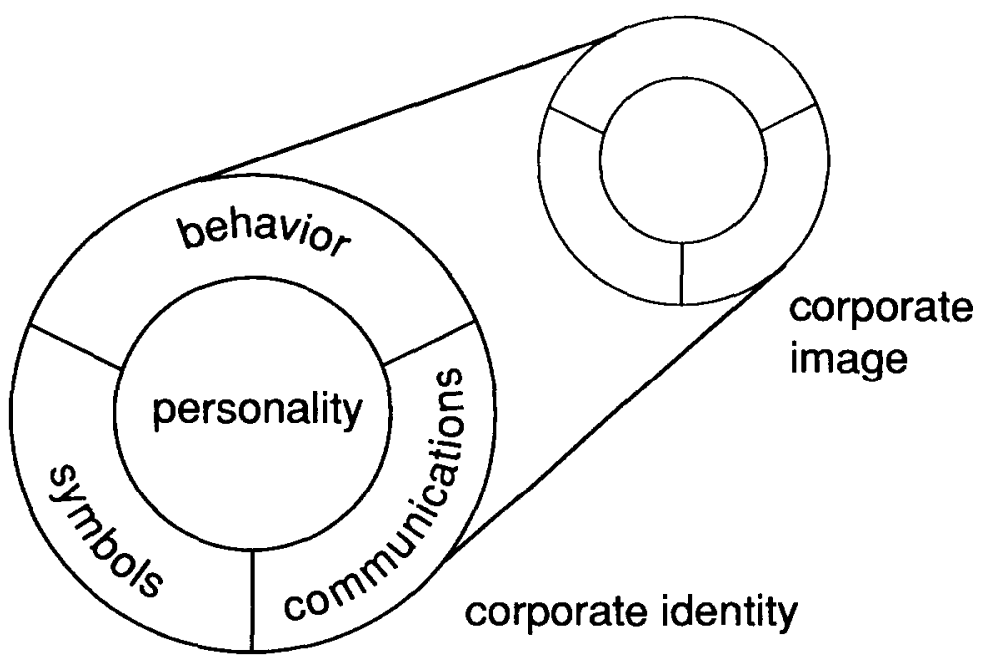

Figure 2. Interaction between Corporate Image and Corporate Identity 


\begin{tabular}{|c|c|c|}
\hline Europe & Banks & Insurance Companies \\
\hline Belgium & $\begin{array}{l}\text { Banque } \\
\text { Bruxelles et } \\
\text { Lambert } \\
\text { Kredietbank }\end{array}$ & $\begin{array}{l}\text { Royale Belge } \\
\text { Equity \& Law } \\
\text { Group AG }\end{array}$ \\
\hline France & $\begin{array}{l}\text { Banque de Paribas } \\
\text { Credit Lyonais }\end{array}$ & U.A.P. \\
\hline Germany & $\begin{array}{l}\text { Deutsche Bank } \\
\text { West Deutsche } \\
\text { Landes Bank }\end{array}$ & Gothaer \\
\hline Great Britain & $\begin{array}{l}\text { Barclays Bank Plc. } \\
\text { Lloyds Bank Plc. } \\
\text { National Westminster } \\
\text { Bank Plc. }\end{array}$ & $\begin{array}{l}\text { Royal Group UK } \\
\text { Legal \& General }\end{array}$ \\
\hline The Netherlands & $\begin{array}{l}\text { AMRO } \\
\text { Postbank } \\
\text { Verenigde } \\
\text { Spaarbank N.V. }\end{array}$ & $\begin{array}{l}\text { Aegon } \\
\text { Nationale } \\
\text { Nederlanden }\end{array}$ \\
\hline
\end{tabular}

Figure 3. Participating Banks and Insurance Companies

\section{METHODOLOGY}

The 21 financial institutions-banks and insurance companies-selected for the survey of communication practices in Europe are not a random sample and cannot, therefore, be relied upon as a source of statistical inferences relating to the whole financial population. Rather, units selected for the investigation from a "purposive sample" shaped more by practical circumstances than statistical requirements. The main reasons for the limited scope of the survey were strictly practical. In addition to financial considerations, accessibility and willingness of individual corporations to participate in the undertaking determined the limitations of the study. In Europe, the selection of financial institutions was confined to five countries.

Once the purpose of the survey was agreed upon, two questionnaires were designed: one $(A)$ to be mailed to participants, asking them essentially for basic background concerning the size of the communication activities, allocation of resources, etc.; the other (B) to be used in personal interviews and containing a number of open-ended questions. This phase of the questionnaire design was completed in March 1988 and both questionnaires were tested with one corpo- 
rate respondent in a bank in the Netherlands, and one in a local bank in the United States. Following this pretest, some minor adjustments were made before interviewing began. In view of the fact that in the European corporations included in the survey, the majority of communication executives know English, it was possible to use one language version of questionnaires only and to avoid some of the pitfalls of translating the exact meaning of some questions from one language into another.

Several of the leading banks and insurance companies in the world were interviewed. According to Business Week's "International Bank Score-board," June 27, 1988, listing the top 200 banks in the world, the Japanese banks and the European banks are dominant. For example, the first 50 banks include 23 Japanese banks and 21 European banks and only four American banks. Eleven of the 50 largest banks in the world (eight in Europe, three in the United States) participated in this survey.

The respondents were identified from various listings of banks and insurance companies, in a few instances they were referred by friends and acquaintances. Essentially, the researchers tried to identify in every bank and insurance company the person in charge of corporate communication, not in terms of overall responsibility but rather in terms of executive experience and familiarity with all the operations, be it advertising, public relations or community and public affairs. It was assumed that internal communication (management-employees) would be in most cases, if not all, under the respondents' responsibilities as well.

\section{RESULTS EUROPEAN SURVEY}

\section{Major Services}

Nearly all banks and insurance companies characterize their services as being active in all facets of financial products. On the average a European bank offers more than 200 different products. In contrast to the United States of America banks, European financial institutions are more specialized.

\section{Number of Employees}

Due to their ranking position in the world, European banks and large insurance companies employ more than 25,000 people. The very large ones (Barclays, National Westminster Bank, Deutsche Bank) each employ more than 100,000 people.

\section{Market Environment}

European institulions appeared to be ratler optimistic about the developments concerning their market share.

Increased competition is nevertheless the general impression of all European respondents. 
As a result of the expected increase of compctition, all the participants saw a need for increased corporate communication efforts, both internally and externally.

\section{Corporate Objectives}

We asked the respondents to describe briefly their company's major objectives. Six main points came forward:

(a) In general banks were more explicit about their corporate objectives than insurance companies. (The same applies to their annual reports.)

(b) Four banks and two insurance companies wanted to be leaders in the world market. Two other banks stressed the importance of being a market leader in their own country.

(c) Broadening the international scope is of great importance for a majority of both banks and big insurance companies. Practically all the banks and insurance companies stressed the importance of adequate preparations to meet challenges of the integrated market in 1992.

(d) Broadening the international orientation was sometimes linked with the perceived necessity to improve the quality of service and/or products. Developing competitive products was especially mentioned in the insurance sector.

(e) Three banks and three insurance companies formulated explicitly a purely economic objective: striving for an increase in profitability or improving the value of shares.

(f) A majority of the insurance companies pointed at the necessity to improve distribution channels.

\section{Corporate Values}

The described corporate objectives focus on the goals to be achieved in the business environment. These goals are directed towards creating a highly distinctive company identity. Realization of busincss goals, partly depending on the business environment, is heavily affected by visible and invisible forces within the organization itself. The invisible, or better, not directly controllable forces within an organization are clustered around the concept of "corporate culture." During the personal interviews, the second part of our data gathering, several questions were asked regarding "corporate culture" and respondents were shown a list of values as shown in Figure 4. All values were perceived as being very important. (with the exception of "friendly relations among employees"). "Education" and "pride of belonging" were mentioned most frequently. 


\section{Pride of belonging to the organization Striving for excellence in performance Teamwork and team spirit Leadership Friendly personal relations among employees Friendly relations with customers Fairness in personnel policy Safety Education and development Creativity and innovation}

Figure 4. Corporate Values

\section{Changes in Corporate Values}

We also asked the participants if they experienced any significant changes in emphasis on corporate values in the recent past and the near future. Most respondents indicated that they were in a process of transition and expect it to continue. Some of the typical statements made in this context were as follows: "In the last decade we had to change our company from a passive, reactive, bank to an active, pro-active, service organization." Another representative of a bank stated: "It used to be a rather feudal organization, now it is more necessary to explain why things are done the way they are done, both internally and externally." The spokesman of a German bank added: "we used to be a 'Beambtenbank' now we have to be a 'commercial service' organization." "Global and national competition forces us to improve the quality of our service," was reported by most respondents. The insurance companies hope to achieve excellence in performance by decentralizing the organization. The reason for this is that decentralization (at this moment) is seen as an ideal organizational structure for the insurance sector.

The four main reasons given by respondents for changes in value orientation were:

\section{(1) Increased competition}

Respondents, both in banks and insurance companies, are fully aware of the threats of the increased competition. The plans to unify the internal European market in 1992 and increased global competition are mentioned by nearly all respondents.

(2) Higher sophistication of the consumer

Less mentioned but nevertheless seen as important by several respondents, was the changes in attitudes among bank clients, both in the retail and wholesale sector. Customers have become more 
critical towards the service offered. The typically European stable relationship with clients seems to have disappeared.

(3) Management style and personal appeal of CEO

Four companies explicitly mentioned the appealing style of management of a recently appointed $\mathrm{CEO}$. In their views the $\mathrm{CEO}$ had had a tremendous impact on changes in corporate culture.

\section{(4) Structural changes}

More than half of the institutions have been, or are, involved in a process of structural changes. Most often mentioned were mergers or the threats of a hostile take-over. Five of the selected companies were, or still are, a public sector institute. All of them felt the necessity to change the (legal) structure (privatizing) or the culture (improving business attitude) as an obligatory reaction to market transitions.

\section{Solutions}

Nearly all respondents underlined the importance of immediately adapting the corporate strategy to the market and the business environment. A successful implementation of corporate strategy seems to be strongly related to the nature of corporate culture within the organization. Banks especially seem to realize that you have to do your utmost to achieve a positive corporate culture. Most interviewed companies had a management development program aimed at improving quality in all aspects of the company (so called quality programs).

\section{CORPORATE COMMUNICATION}

\section{Introduction}

Over the last decade, a number of banks and insurance companies have developed increasing sophistication in communication strategies contributing to the rcalization of the corporate goals. Sullivan states in the Journal of Retail Banking (winter 1985/86) "corporate communication is entering a stage of maturity." His conclusion is checked in our survey: Do they try to attune all forms of internal and external communication to each other? And if so, how do they apply the corporate communication function in their company, e.g. what kind of organizational structure do they use?- how many people do they employ in this area?-and what communication strategy do they follow?

\section{Number of Employees in Communication}

The total number of communication professionals varies from 1 to 120 . The banks have much more inside communication professionals 
than the insurance companies. The top four of the European banks in this survey have 40 to 100 communication professionals as staff members. The top three of the insurance companies have about 50 employees. Most communication professionals work within the "border" of the marketing department, others in the external communication department (public relations, public affairs, and corporate advertising) and a minority in the internal communication department.

\section{Budgets}

The majority of the banks and insurance companies reported that they spend about $60-70$ percent of their budgets on marketing communication information indicated they are spending of about 10 percent of their budgets on internal communication. It is possible that this relatively low figure has to be seen as part of the money spent by Human Resource departments on management development, where complementary activities take place, e.g. training programs to improve motivation.

\section{Organization of Corporate Communication}

The survey explored three departments in which image building elements are to be found. The marketing department responsible for the selling and advertising of scrvices and products; the institutional department that deals primarily with the promotion of the corporate image, (public relations, public affairs, investor relations and corporate advertising); and finally the internal communication department where the communication with the own employees is initiated.

Although there are major differences in the organization of corporate communication in banks and insurance companies some striking similarities appear. Nearly all the interviewed institutions were in the middle of a process of organizational change concerning their corporate communication department. Often this process was aimed at breaking down formal borders between the originally independent communication departments (marketing, public relations, public affairs, and employee communication) in order to create an organizational structure in which coordination of activities is possible. A vast majority of the respondents tried to achieve this situation through coordination in terms of management. One of the most often mentioned problems in this respect is the coordination between the "traditional" marketing department and the "other" departments. Harmony between communication departments is achieved through formal and informal structures. Appointing a director in charge of all the existing communication departments can be considered only a formal organizational solution. The majority of the interviewed companies tried to solve the problem of coordination through informal procedures, e.g. weekly or monthly meetings, sharing information about the planning of communication activities in the near future (month, year), ad hoc meeting, etc.

In general, executives in charge of corporate communications report directly to the top management of the bank or the insurance company. Sometimes there are 
one or two layers between the communication department and the CEO. In this case the head of corporate communication reports to an intermediary directly beneath the board of directors. This does not mean that there is no direct contact between the communication people and the top management of the organization. As a matter of fact there appears to be frequent informal contact between the communication executive and the corporation's top officers. We can conclude that a typical organizational chart for corporate communication does not exist.

\section{Names of Departments}

The term "corporate communication" is not broadly adopted in the banking and insurance world, although it was mentioned quite often. The departments have a variety of titles; internal and external communication, corporate communication, marketing communication, public relations, press contacts, public affairs or simply "communication." Job or department titles are unreliable guides to duties and responsibilities. With different titles from one company to the next, senior corporate communication executives often have similar responsibilities. The same title may also hide differences.

\section{Communication Objectives}

Asked how they would formulate their corporations' major communication objectives, two trends became apparent:

(1) Most communication objectives are externally oriented. The internal function of communication does not get much attention.

(2) Expressed in many variations, banks and insurance companies stress the importance of: (a) making clients aware of products and services of their institutions; (b) creating a desired positive attitude towards the company in general, as well as their specific products; and (c) to stimulate clients to buy products or services of the institution.

Figure 5 illustrates the variety of communication objectives used by banks and insurance companies.

The similarity of objectives among financial institutions makes it dificult for an individual bank or insurance company to position itself as an unique business asset. The contents and design of corporate communication messages confirm the assumption that there is "much of the same" in the financial service sector.

\section{Trends in Positioning Statements}

Formulating a positioning statement, in communication, means clarifying and underlining the unique selling points of an organization. Looking at the answers regarding positions one has to conclude that finding an original and unique positioning is difficult. They all use the same ingredients: reliability, competence, service orientation, market leadership and, if applicable, 


\begin{tabular}{|c|c|c|}
\hline & Internal communication & External communication \\
\hline \multirow[t]{3}{*}{$\begin{array}{l}\text { Rational } \\
\text { goals }\end{array}$} & $\begin{array}{l}\text { Improving understanding } \\
\text { of own business }\end{array}$ & Increasing name awareness \\
\hline & & Increasing product awareness \\
\hline & $\begin{array}{l}\text { Task oriented communication } \\
\text { what is expected of everyone }\end{array}$ & Explaining business strategy \\
\hline $\begin{array}{l}\text { Emotional } \\
\text { goals }\end{array}$ & $\begin{array}{l}\text { Increasing involvement own } \\
\text { employees } \\
\text { Expressing care for own } \\
\text { employees }\end{array}$ & $\begin{array}{l}\text { Influencing attitudes; } \\
\text { creating a positive image in order } \\
\text { to simplify a commercial relation, } \\
\text { networking; influencing } \\
\text { opinion leaders }\end{array}$ \\
\hline \multirow[t]{3}{*}{$\begin{array}{l}\text { Desired } \\
\text { actions }\end{array}$} & $\begin{array}{l}\text { Increasing self consciousness } \\
\text { through external (image) } \\
\text { communication }\end{array}$ & $\begin{array}{l}\text { Specifically for insurances } \\
\text { companies, improving direct } \\
\text { relations with clients }\end{array}$ \\
\hline & $\begin{array}{l}\text { Improving service } \\
\text { orientation }\end{array}$ & $\begin{array}{l}\text { Persuading clients to buy, } \\
\text { satisfying shareholders }\end{array}$ \\
\hline & & $\begin{array}{l}\text { Persuading clients to remain } \\
\text { customer }\end{array}$ \\
\hline
\end{tabular}

Figure 5. Communication Goals

offering an international infrastructure. With the exception of the Dutch and the German banks, all organizations "translate" the positioning statements in messages directed at emotions. The identification of the individual banks or insurance companies becomes clearer through the often appealing slogan and the logo used.

\section{Corporate Symbols}

Corporate identity used to be thought of strictly in terms of design, graphic logotypes, and symbols per se (Wathen, 1986). According to our findings, identification markers such as logos, slogans, and color are seen by all respondents as inseparable from the overall image an organization wishes to create of itself. Doubtless, these corporate symbols are an ideal instrument to visually distinguish one's own company from competitors. A majority of the respondents in our survey only wanted to visualize their corporate name in an attractive way and did not use corporate symbols as a graphic expression of their corporate strategy. About one third of the respondents claimed the opposite. 
Only three (insurance) companies had doubts about the awareness of the central symbol by both employees and the general public. The majority of the Furopean respondents were convinced that their corporate symbols are well known by their target groups. "Well known" to them meant that the symbols are recognized, with or without the corporate name, but companies were unsure as to whether the meaning of the symbols were understood.

Two banks used an animal to symbolize a specific characteristic of their corporation. The Postbank uses a lion as a symbol of strength, stability and reliability. Lloy'ds uses a black horse to personify a "thoroughbred" bank. The long history of some European banks and insurance companies makes it possible to use a historical symbol: a coat of arms like the eagle with three crowns in its wings (Barclays), a shield as a sign for the protection offered by Royal, or the symbol for Justice as a sign of faimess in commercial relations applied by Equity and Law.

The more modern versions of logos can be divided into two categories: representational symbols and non-representational symbols. Only five organizations in the survey use abstract geometric symbols. Their connotations were described in general terms such as strength, future orientation (Deutsche Bank) or representation of the rising and setting of the sun as a symbol for the 24-hoursa-day service through the Credit Lyonnais branches all over the world, or the Royale Belge symbol characterizing activity and productivity.

Nearly all the symbols were created ten years ago. A few organizations, however, have been using the same logo for many decades. Mergers and takeovers within and between the banks and insurance companies will necessitate the creation of new symbols. These new labels will have to be distinctly different from the old ones and capable of reducing the confusion in the eyes of the beholder. The banks and insurance companies that will be able to remain independent will have the big advantage of continuing to use their traditional and well known symbols, creating a competitive advantage to the previous group of companies in the battle for positions on the "recognition-ladder" in the mind of the target groups.

\section{Communication Strategy}

When the communication strategies used by the European banks and insurance companies were compared, a pattern of similarities became clear.

In the case of marketing communication all media are employed: mass media, brochures, interpersonal communication (direct mail, specches), ctc. In the United Kingdom television is seen as an important medium. The four other countries, especially West Germany and Belgium, hardly mention television as a marketing-tool. Print media were used most frequently by both banks and insurance companies. The second most frequently used mediums were magazines (banks) and leaflets (insurance companies). Remarkable was the lack of interest in direct mail as a marketing instrument.

Banks describe their major target audiences in rather general terms, such as: "retail market," "young people," “customers," etc. Insurance companies men- 
tion, with only one exception, the intermediaries/agents as their most important target group. Only one financial service institution mentioned "opinion leaders" as an important target group for marketing communication.

Promoting the corporation's image among various publics, the so called institutional communication (public relations, public affairs, investor relations, and corporate adverting) is considered to be a vital aspect of the corporate communication function. Relations with financial target groups are seen as particularly important by all European respondents. A basic instrument for informing financial target groups is the annual financial report. All banks and insurance companies produce an annual report. Reading these reports one has to conclude that most organizations see their annual report not only as a formal legal requirement but also as an image building instrument.

Good relations with the community at large and with the government are also seen as important. Communicating with these target groups is mostly the responsibility of the public relations department. In the perception of the majority of survey respondents, public relations work in their corporation is very similar to that performed by competitors.

The overall picture of media use in institutional communication is comparable with the above mentioned results regarding marketing communication. In addition to the media that are used to promote the services and products of the organization, typical image building media or techniques are employed. For example, free publicity, corporate advertising (paid publicity), sponsoring, giveaway presents. More sophisticated image building approaches, especially in the banking sector, are speeches, summer courses for university students, and research papers concerning market developments such as the Forecasting Series of the Westdeutsche Landesbank.

Banks and insurance companies choose different target groups for their institutional communication. Due to the importance of their main distribution channels, insurance companies focused primarily on their intermediaries. Banks ranked the general public, customers, and potential customers as number one or two in order of importance.

The majority of the respondents saw an increased need for employee communication. Media used for employee communication are: in-house-publications, meetings, handbooks, training programs, bulletins, employee orientation programs and surveys of employee satisfaction. In-house publications were used most by banks and insurance companies. Training programs, important for task oriented communication and for communication aimed at improving motivation, were mentioned most frequently by banks. The survey shows that all our respondents regularly communicate with retirees and pensioners.

\section{IMAGE}

Attuning the corporate objectives to communication goals, translating the latter into a positioning statement and finally choosing a carcfully 
planned communication strategy, does not guarantee that the desired image of a company will be in accordance with the actual image as perceived by the main stakeholders of the company.

A majority of the respondents had a clear view about two elements of perceived reputation. With only three exceptions banks and insurance companies were satisfied with the public awareness of their company.

One can conclude that the interviewed companies have a favorable perception of their own reputation among competitors.

\section{Evaluation Method}

The above judgments of the respondents were mostly based on systematic measuring of effectiveness of external and internal communication. Employee surveys were used by nearly all respondents. A majority of the participating companics used several methods to evaluate the effectiveness of communication ranging from simple techniques like "monitoring the corporation's business volume" and informal discussions with clients to "analyzing comments in media" and "surveys of customers' attitudes and opinions." From among the evaluation methods respondents identified, the following three were most frequently used: monitoring business volume, surveys of customer's attitudes, and opinions and analyzing comments in media.

\section{USA or Europe As Precursor of Innovation in Corporate Communication?}

Some professionals suggest that corporate communication practices and corresponding theories in the United States influence the whole corporate world. Illustrations for this influence can be found in the overwhelming amount of book titles of American origin in the field of corporate communication. Another example is the popularity of American speakers on European conferences. On the other hand we see an increasing tendency to develop typical British, German or French, etc., forms of corporate communication. To illustrate this: all the five countries visited for our interviews had their own corporate communication handbook and most European respondents felt the necessity to develop their own "corporate communication style" fitting within the national culture.

A majority of the respondents believed that cultural characteristics had an impact on corporate communication. In other words, they did realize that it is not possible to "translate" American developments into the national or even European context of corporate communication.

Asked, more generally, who's influencing whom in corporate communication, the majority of the respondents said they simply could not tell because they hardly knew the state of the art of corporate communication in comparable American institutions. Only four financial service organizations had the opinion that the way in which public relations was performed in the United States was influencing 
Europe and the same number of respondents thought that the center was shifting to Europe.

\section{REFERENCES}

Birkigt \& Stadler. (1986). Corporate Identity. Landsberg am Lech.

International Bank Score-board. (1988). Business Week, June 27.

Sullivan. (1985-1986). "The Maturing of Corporate Communications." Journal for Retail Banking, (Winter): 25-32.

Wathen, M. (1986). "Logomotion, Corporate Identity Makes its Move into the Realm of Strategic Planning." Public Relations Journal, (May) : 24-29. 